briefly in the paper, and were enlarged upon by several speakers in the discussion which followed the reading of the paper.

\section{Deep-Sea Observations with the Bathysphere}

Foun years ago, Dr. William Beebe and Mr. Otis Barton descended in their 'bathysphere'- - a steel ball fitted with quartz windows - to a depth of a quarter of a mile below the surface of the ocean off Bermuda. During the season of 1934 they successfully established a new depth record of $3,028 \mathrm{ft}$. In the $\mathrm{National}$ Geographic Magazine of December 1934 and the Bulletin of the New York Zoological Society of November-December 1934, interesting articles deal with the fitting-out, operation and scientific observations made, during these latest dives. Excellent photographs in the text provide a word picture of the undertaking, and a series of coloured plates give vivid impressions of the strange and bizarre forms of life as seen by Dr. Beebe through the windows of the ball and described over the telephone line between the bathysphere below and the parent ship at the surface. Three deep-sea fish, new to science, are described, including the five-lined constellation fish, Bathysidus pentagrammus, which Dr. Beebe speaks of as one of the most gorgeous deep-sea inhabitants he has ever seen. Five rows of photophores emitting yellow and purple light produced a beautiful pattern of illumination through the darkness. From this and other records, there can be little doubt as to the success and scientific value of this daring method of observa

\section{Optical Research}

Ar the meetings of the Institut d'Optique, held periodically at the Sorbonne and generally under the chairmanship of Prof. Charles Fabry, director of the Institut, the communications considered relate as a rule to one particular branch of the subject, and the Revue d'Optique Theorique et Instrumentale issues a separate copy of the proceedings which may run to as much as 50 pages. Last year, the January meeting dealt with the employment of liquid prisms in spectrographs, that of March with interference methods of studying movements of the air, the April meeting with ultra-violet polarimetry and with the densities of photographic images, and the June meeting with the light of the night sky. In several cases the subject is introduced by a short sketch of past work on it and its present aims and problems, given by the president, and descriptions of current methods and instruments by specialists in the subject follow. These pamphlets seem capable of affording great assistance to those requiring brief résumés of the present positions of the various branches of optical research.

\section{Systematics of the Diptera}

Mr. P. H. Grimshaw has recently published a useful article entitled "Introduction to the Study of Diptera, with a Key for the Identification of Families" (Proc. Roy. Phys, Soc., Edin., 22, Pt. 4, July 1934). The paper gives a clear account, accompanied by illustrations, of the various structural features of importance in classification. A list of the chief general works on the order is provided and a diagnostic key to all the existing families. The key is translated and adapted from Lindner's "Fliegen der palaeartischen Region" and should prove especially valuable to those entomologists who are not specialists in the insect order concerned.

\section{Review of Seismology}

THE National Research Council of the National Academy of Sciences at Washington is issuing a series of bulletins on the physies of the earth, to give scientific workers who are not specialists in the subjects treated an idea of the position and problems of various branches of geophysics. Among the bulletins in this series which have already been issued are those on volcanology, the figure of the earth, meteorology, the age of the earth and oceanography. Recently, Bulletin No. 90 on seismology has appeared. It has been prepared by a Committee of which Prof. J. B. Macelwane is chairman. Within 219 pages it includes twenty chapters, and gives a very valuable and interesting general view of the subject. Chapters by the chairman include-the definition and classification of earthquakes, tectonic earthquakes, plutonic earthquakes, rock fall earthquakes, body waves, reflection and refraction of seismic waves, surface waves and paths and velocities of seismic waves within the earth; H. O. Woods contributes articles on volcanic earthquakes, field investigation and surface geology in relation to the 'apparent' intensity ; articles by H. F. Reid deal with magnetic effects, earthquake mechanics and with the focus. The principle of the seismograph is described by J.A. Anderson, and P. Byerly contributes five articles on analysis of seismograms in earthquakes, records at intermediate and great distances, time distance curves, reduction of trace amplitude, and seismic geography. The Bulletin has numerous bibliographies and is priced at 2 dollar

\section{Books on Anthropology and Archazology}

Catalogue No. 574 (Anthropology and FolkloreArchæologyand Ethnography)issued by Messrs. Francis Edwards, Ltd., 83 High Street, Marylebone, London, W.1, including both new and second-hand books, though, naturally, the latter predominate, contains just under a thousand items. On looking through the list, two points occur, one being the high average in the quality of the books from the point of view of the anthropologist, and secondly the fact that, with certain exceptions, the prices do not rule high. With regard to the first point, the subjects covered by the catalogue, it is almost needless to say, have been a happy hunting ground for the wilder theorist and speculation has been rife in their literature. It is evident that here on the whole a wide discretion has been exercised in selection. The question of price is no less interesting. It is not intended to convey that this catalogue is an exceptional opportunity for bargain hunters-although it would be possible to form from its pages an excellent nucleus of a reference 